\title{
ガラス含浸炭素材料の試作
}

\author{
池田茂・堀昭 二・藤井禄郎・松尾寛二 \\ 江口清久・在間秀典*・蒲田義史 ${ }^{*}$
}

\author{
(昭和 60 年 3 月 11 日受理)
}

\section{Trial Production of Carbon Material impregnated with Glass}

\author{
Shigeru Ikeda, Shoji Hori, Rokuro Fujii, Kanji Matsuo, \\ Kiyohisa Eguti, Yoshinori Zaima* and Yoshihumi Gamada* \\ Government Industrial Research Institute, Osaka \\ Midorigaoka 1-8, Ikeda, Osaka, 563 Japan \\ * Kyowa Carbon Co., Ltd. \\ Nishinakajima 1-11-16, Yodogawa-ku, Osaka, 532 Japan
}

\begin{abstract}
A new type of impermeable carbon material which is resident against oxidation in air at the temperature up to about $900^{\circ} \mathrm{C}$ has been developed. The material was prepared by impregnating its pores with molten glass such as borosilicate. Even when heated for 1.5 hours in air at a temperature of about $900^{\circ} \mathrm{C}$, its weight loss was only about $10 \%$. The oxidation proceeded very slowly at $750^{\circ} \mathrm{C}$ and $900^{\circ} \mathrm{C}$, and the oxidation rate at $800^{\circ} \mathrm{C}$ was only $1 / 50$ th of that of nontreated graphite.

The other characteristics such as mechanical strength, Young's modulus and gas impermeability of the carbon material were also considerably improved by impregnating with glass.
\end{abstract}

\section{1. はじめに}

一般の炭素製品は,コークスなどの骨材とコールター ルピッチなどの結合材を混杍つ, 成形, 焼成, 炭化, お よび $2500^{\circ} \mathrm{C}$ 以上での熱処理による黒鉛化の工程を経て 製造される。乙の場合, 骨材であるコークス中に存在す る気孔のほかに, 製造過程で結合材中の揮発分が逸散し てできる気孔ともあわせて, 通常の黒鉛材料は10３0％ 程度の気孔率を持っている。

黒鉛材料中の乙の気孔は, 気体抢よび液体に対する不 浸透性, 耐酸化性, 機械的な強度等を低下させる原因と なっている。

そのためてれまでに, フェノール, フォルムアルデヒ ド樹脂などのような合成樹脂, コールタールピッチ, 金 属類, リン酸塩等を含浸したり,または, 炭化ケイ素を

大阪工業技術試験所：干563 池田市緑ケ丘 $1-8$

*協和カーボン(株) : $\mathbf{T} 532$ 大阪市淀川区西中島 $1-11$

$-16$
被覆することによって, 不浸透性, 耐酸化性, 機械的強 度等を向上させることが行われてきた ${ }^{1,21}$ 。

しかし，乙れまでの有機高分子や鉛，ホワイトメタル 等の金属類は，比較的低温度で熱分解するかまたは溶融 する。リン酸塩などを含浸処理する場合は, 水溶液とし て常温で含浸処理することが可能であるという利点があ る屯のの，乙れもまた低温で溶融ないしは分解すると云 う欠点があり，いずれも高温に扔いて炭素材料に耐酸化 性を付与させる方法としては不適当である ${ }^{3,4,5)}$ 。

黒鉛材料に対するガラス含浸処理の研究は，乙れまで 筆者らの研究室で, 比較的低溶融点をむつ鉛ガラスや小 ウ酸ガラスを対象に研究を進めてきた。しかし, 鉛ガラ スは, 黒鉛材料への高温での圧入含浸処理時にガラス中 の酸化鉛が炭素材料と反応して還元され金属鉛となり易 いが, 乙の際炭素が部分的に酸化されるので含浸材料と しては適当ではなかった。他方, ホウ酸ガラスは, 鉛ガ ラスのような還元反応を起さず機械的任優れた特性を示 したが, ホウ酸ガラスに特有の耐薬品性の弱さがあり, 
このため，実用的な材料とはなり得なかった ${ }^{6,7,8)}$ 。

本報告は, 耐熱性, 耐薬品性の大きい黑鉛材料を含浸 処理法によって得ることを目的としたもので, 従来の低 溶融点ガラス含浸材料よりは高温特性の優れたホウケイ 酸ガラスを黒鉛材料の細孔内に含浸処理したものについ て，いくつかの興味ある特性が得られたのでそれを報告 する。

\section{2. 実験}

\section{1 原 料}

含浸処理実験には，製鋼用黑鉛電極材料 (協和カーボン K.K.のニップル材)から $250 \mathrm{~mm} \phi \times 250 \mathrm{~mm}$ のの大き に切り出したものを黒鉛材料の試料として用いた。黒鉛

Table 1 Characteristics of graphite electrode (nipple) used as carbon sample

\begin{tabular}{ll|c} 
& & \\
\hline Bulk density & $(\mathrm{g} / \mathrm{m} l)$ & 1.60 \\
Porosity & $(\%)$ & 26.9 \\
Compressive strength & $\left(\mathrm{kgf} / \mathrm{cm}^{2}\right)$ & 155 \\
Bending strength & $\left(\mathrm{kgf} / \mathrm{cm}^{2}\right)$ & 78 \\
Young's modulus & $\left(\mathrm{kgf} / \mathrm{mm}^{2}\right)$ & 793 \\
Electric resistance & $(\mu \Omega \mathrm{cm})$ & 750 \\
CTE & $\left(10^{-6} /{ }^{\circ} \mathrm{C}\right)$ & 4.5 \\
Viscous permeability coefficient & \\
& $\mathrm{B}_{0} \mathrm{~cm}^{2}\left(10^{-8}\right)$ & 2.5
\end{tabular}

Table 2 Composition and properties of borosilicate glasses as impregnant

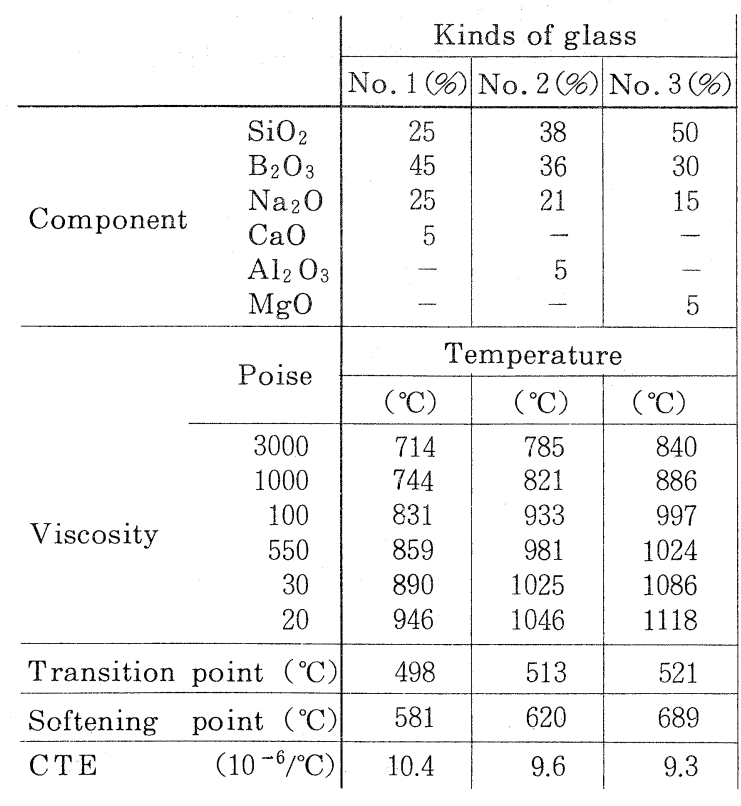

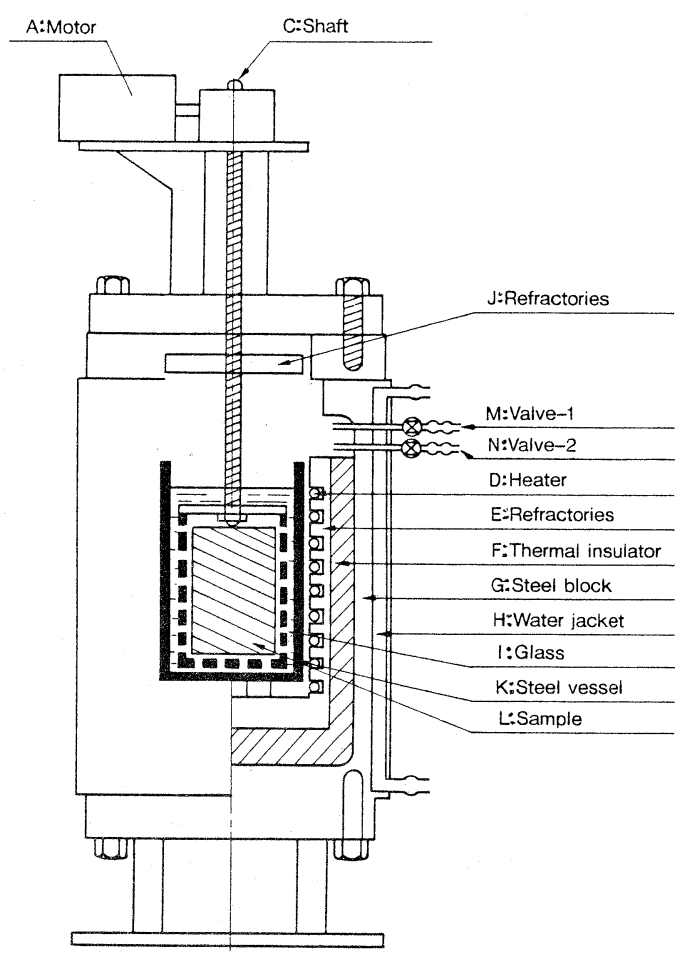

Fig. 1 Apparatus of glass impregnation

電極材料の諸特性を Table 1 亿示す。また, 含浸材 料としては, Table 2 に示した組成および特性をも つ， 3 種類のホウケイ酸ガラスを用いた。

\section{2 含浸処理実験}

含浸処理実験には, Fig. 1 に示すような内熱式 のオートクレーブを使用した。黒鉛材料に含浸させ るために必要な量のフリットにしたホウケイ酸ガラ スをステンレス製のルツボに入れ，乙のルツボをオ ートクレーブの中に入れた。黒鉛材料はステンレス 製のかでに入れ，オートクレーブの上部につるした。 真空ポンプでオートクレーブ内を 1 Torr 以下に減 压にしながら，オートクレーブ内に内蔵されている カンタル発熱体で, 昇温速度 $10^{\circ} \mathrm{C} / \mathrm{min}$ で加熱した。 オートクレーブ内の温度を, 含浸材料であるNo.1 のガラスの場合は, $950^{\circ} \mathrm{C}$, No. 2 のガラスの場合 は, $1050^{\circ} \mathrm{C}$, No. 3 のガラスの場合は, $1100^{\circ} \mathrm{C}$ そそ れぞれ上昇させ，ガラスが十分溶融した後，黒鉛材 料の入ったかでをモーターで下げ, 溶融しているガ ラス中に浸漬した。その後, 真空ポンプを切り, 才 ートクレーブ内に窒素ガスを所定の压力 (1～75kg/ $\mathrm{cm}^{2}$ ) で導入し, 一定時間保持して溶融ガラスを黒 
鉛材料の細孔内に圧入し，含浸処理を行った。

\section{3 諸特性の測定}

カサ密度は, $10 \mathrm{~mm} \times 10 \mathrm{~mm} \times 10 \mathrm{~mm}$ に切り出した ブロックの重量から算出した。気孔率は, 含浸処理前の 気孔率に対する含浸処理されたガラスの容積率の差とし て求めた。含浸率は, 含浸処理前の気孔率に対する含浸 処理後の気孔率の比である。

压縮強度の測定は，カサ密度を測定した試料について 行った。曲げ強度は, $5 \mathrm{~mm} \times 5 \mathrm{~mm} \times 40 \mathrm{~mm}$ の試料に ついてスパン $30 \mathrm{~mm}$ の 3 点曲げ試験で測定した。

ヤング率は, 共鳴振動法で, 電気比抵抗は電圧降下法 で，いずれも $10 \mathrm{~mm} \times 10 \mathrm{~mm} \times 100 \mathrm{~mm}$ の角柱試料に ついて測定した。熱膨脹係数は, 理学電機社製の示差熱 膨脹計を使い, $100 \sim 300^{\circ} \mathrm{C}$ の間に掞ける膨脹をアルミ ナを標準として測定した。それぞれの測定個数は10個と し，ガラス含浸黒鉛材料のあらゆる場所から採り，それ らの平均值を求めた。

不浸透性の効果を調べるために, ガス透過率测定装置 を用いてガス透過率を測定した。 $19 \mathrm{~mm} \phi \times 800 \mathrm{~mm} l$ の 円柱状の試料の両端の一方に窒素ガスで $1 \mathrm{~kg} / \mathrm{cm}^{2} \sim 5 \mathrm{~kg}$ $/ \mathrm{cm}^{2}$ の压力を加え, 他方に $10^{-4}$ Torr の真空系を接続 させ,その間でガス透過量を測定し, 試料 5 個の平均值 を求めた。乙の場合, 試料の側面はゴム薄板で覆い外部 加压力を加えて密着させるととにより試料側面からの ガスのリークを防止した。

細孔分布は, Carlo-Erba 社製の水銀ポロシメータ 一を使用し, $8 \mathrm{~mm} \times 8 \mathrm{~mm} \times 20 \mathrm{~mm}$ の試料について $1000 \mathrm{~kg} / \mathrm{cm}^{2}$ まで測定し, Kelvin式によって計算した。

酸化消耗試験は, 理学電機社製の DTA-TGA装置を 用い, 昇温速度を $10^{\circ} \mathrm{C} / \mathrm{min}$, 乾燥空気を $50 \mathrm{cc} / \mathrm{min}$ の の流量で流しながら $650 \sim 1100^{\circ} \mathrm{C}$ の温度範井で測定した。

また, 一定温度に扔いて, 酸化消耗量の時間変化を熱 天秤を用いて測定し, 酸化の反応速度定数を求めた。乙 の際, 含浸されたガラス量を差し引いた炭素のみに対す る消耗量として計算した。

組織観察は，偏光顕微鏡と走查型電子顕微鏡を用いて 行った。

\section{3. 結果と考察}

Fig. 2 は, 黒鉛材料にNo. 2 のホウケイ酸ガラスを 含浸処理した場合の含浸率と圧入ガス圧との関係を示し たあのである。

含浸率は，常圧より含浸圧力が高くなるに従って急激 に増加し， $20 \mathrm{~kg} / \mathrm{cm}^{2}$ 付近で58\%に達した。それ以上の 圧力下では緩やかに上昇した。黒鉛材料は，それぞれの 固有の細孔分布を持ち, マクロポアーといわれる比較的

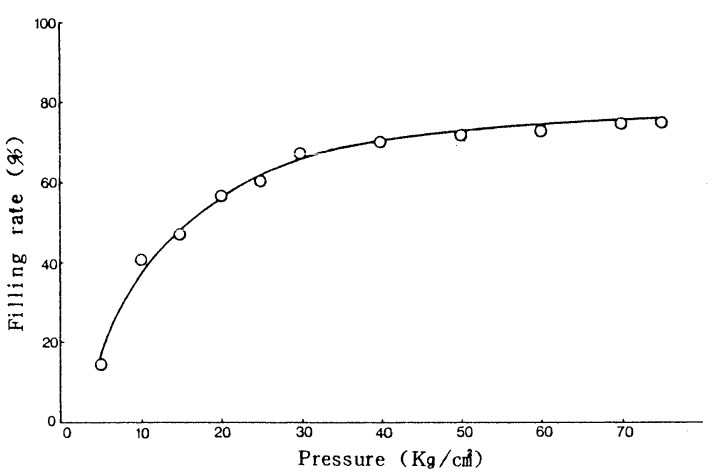

Fig. 2 Relation between impregnation pressure and filling ratio with glass into carbon materials at $1100^{\circ} \mathrm{C}$

大きい細孔径と, ミクロポアーといわれる微細孔径と からなっている。黒鉛材料へのガラスの含浸過程は, ま ず最初, 比較的大きい細孔内へガラスが含浸され, さら に含浸を進めるためにガス圧を上げることにより, 微細 孔へガラスが含浸されるが, その速度は初期段階に較べ てはるかに遅くなる。

ガラスの圧入含浸処理前後に打ける黒鉛材料の細孔径 一細孔容積累積曲線の変化を Fig. 3 に示す。含浸処理 前の黒鉛材料の兒積曲線は, 直径 $10 \mu \mathrm{m}$ 付近で急激に上 舁し，それ以下では， $0.3 \mu \mathrm{m}$ 付近にやや大きい上昇を 含め全体として緩やかな上昇傾向が $0.03 \mu \mathrm{m}$ 付近まで継 続した。乙の黑鉛材料は, $10 \mu \mathrm{m}$ 付近に大きく鋭いピー クと $0.3 \mu \mathrm{m}$ 付近に小さくブロードなピークとよりなる 細孔分布曲線を屯つてとがわかる。

てれに対して, 含浸処理後の黒鉛材料は, 直径 $4 \mu \mathrm{m}$

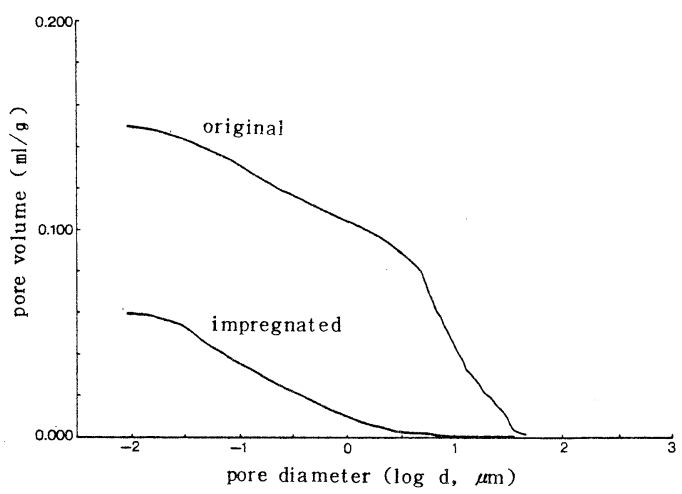

Fig. 3 Accumulative curves of pore volume for glass impregnated and original carbon 
以上の細孔がほとんどなくなり，それ以下の直径をむつ 細孔が残存した。この中には，ガラスを圧入しえなかっ た細孔の他に，黒鉛の熱膨脹係数 $4 \times 10^{-6}{ }^{\circ} \mathrm{C}^{-1}$ とガラス の $1 \times 10^{-5}{ }^{\circ} \mathrm{C}^{-1}$ との差によって冷却時に生ずる細孔内 空隙屯含まれていると考えられる。

Table 3 に, ホウケイ酸ガラスを含浸処理した黒鉛材 料の諸特性值を示した。

今回の含浸処理実験で使用した黒鉛材料は，製鋼用黒 鉛電極材料であり，その製造法からみて閉気孔が比較的 少ないので, No.1のガラスで $69.4 \%$ 屯の高い含浸率が 得られたと考えられる。

機械的な強度は，ガラス含浸処理によって著しく増大 し, 含浸処理前の黒鉛材料と較べて圧縮強度が約 2 倍に, 曲げ強度が約 2.5 倍に大きくなった。

電気比抵抗は，ガラス含浸処理によってもほとんど変 化しないてとがわかった。

Table 3 Characteristics of carbon sample impregnated with No.1, No. 2 and No. 3 glasses

\begin{tabular}{ll|r|c|c|}
\multirow{2}{*}{} & & \multicolumn{3}{|c|}{ Kinds of glass } \\
\cline { 3 - 5 } & & No.1 & No.2 & No.3 \\
\hline Bulk density & $(\mathrm{g} / \mathrm{m} l)$ & 2.06 & 1.99 & 2.00 \\
Porosity & $(\%)$ & 8.2 & 11.1 & 10.7 \\
Filling ratio of glass & $(\%)$ & 69.4 & 58.9 & 60.4 \\
Compressive strength & $\left(\mathrm{kgf} / \mathrm{cm}^{2}\right)$ & 363 & 339 & 347 \\
Bending strength & $\left(\mathrm{kgf} / \mathrm{cm}^{2}\right)$ & 189 & 196 & 195 \\
Young's modulus & $\left(\mathrm{kgf} / \mathrm{mm}^{2}\right)$ & 1763 & 1809 & 1810 \\
Electric resistance & $\left(\mu \Omega \mathrm{cm}^{2}\right)$ & 786 & 780 & 773 \\
CTE & $\left(10^{-6} /{ }^{\circ} \mathrm{C}\right)$ & 5.2 & 4.9 & 4.8 \\
Viscous permeability coefficient & & & \\
\multicolumn{1}{c|}{$\mathrm{B}_{0} \mathrm{~cm}^{2}\left(10^{-12}\right)$} & 2.1 & 7.4 & 5.3
\end{tabular}

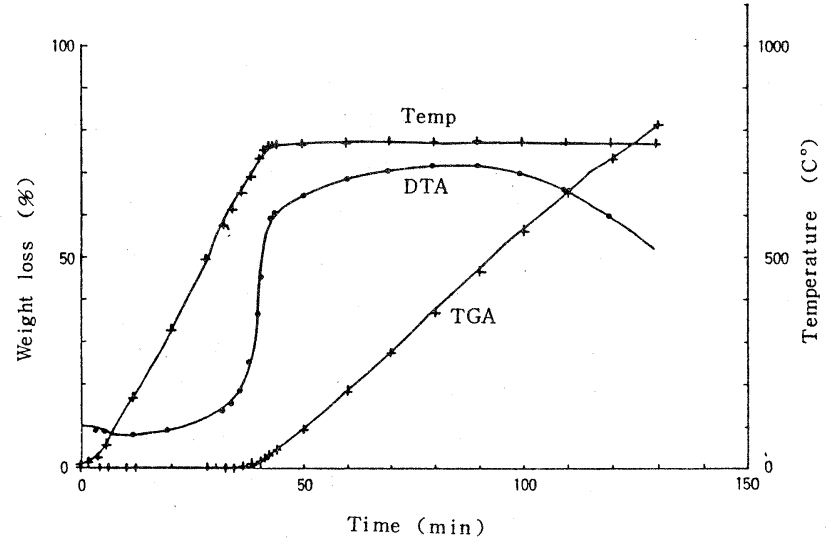

Fig. 4 DTA, TGA and temperature rising curves up to $750^{\circ} \mathrm{C}$ for original carbon in $50 \mathrm{ml} / \mathrm{min}$ of air flow rate
粘性流透過係数 B0 は, No.1 のガラスを含浸処理し たものが最も小さく, 次いでNo.3のガラスのもの, No.2のガラスのものは最も大きい值であった。てれら の值はガラス含浸率に反比例することを示唆し，また， 全体としてガラス含浸処理がかなりの不浸透性の效果を あたらすととが明らかになった。

Fig. 4, 5, 6, 7 は, 含浸処理前の黒鉛材料之No. 2 の ガラスを含浸処理した後の黒鉛材料について, 熱天秤を 用いて空気気流中で $750^{\circ} \mathrm{C}$ および $900^{\circ} \mathrm{C}$ まで昇温し，そ の温度に保持した時の重量減少と示差熱变化を示したも のである。

Fig. 8, 9 は, 含浸処理前の黒鉛材料と No. 2 のガラ スを含浸処理した黒鉛材料について, $675^{\circ} \mathrm{C} \sim 1100^{\circ} \mathrm{C}$ ま での各温度で空気気流中で酸化させた時の消耗率を, 時 間に対して表わした酸化速度曲線である。

Fig. 4 では, 炉内温度が $750^{\circ} \mathrm{C}$ に達すると酸化がはじ まり，極めて単調に重量が減少する。減少 速度は, $0.95 \% / \mathrm{min}$ で DTA 曲線も著し い発熱を示す。Fig. 5 ではさらに，減少速 度は $1.67 \% / \mathrm{min}$ と大きくなるとと, 120 分 でほぼ完全に酸化消滅することがわかる。 これに対して, Fig.6，7 では，昇温過程 に扔いて, 若干酸化が起り DTA 曲線にも 発熱ピークを示す。しかし, 所定の温度に 達してからは, 酸化による重量減少は止ま り，横這状態となり，同時にDTA曲線に よる発熱反応も見られなくなる。乙れは, 初期段階で試料の表面層の炭素が DTA 曲 線上の発熱ピークに相当する量だけ酸化さ れ，乙の酸化によって表面層に含浸されて いるガラスが露出し, その後の昇温で溶融 して表面上にガラスの薄膜を形成するため である。またてのガラス薄膜は, 試料内部 の溶融状態にあるガラスの表面への浸み出 しによっても形成されるので, 試料の表面 がかなり厚いガラス膜で被覆されるように なる。高温で保持した時の酸化消耗速度の 減少は, 乙の膜による酸素の拡散速度の低 下によってあたらされるものと考えられる。 このことは，それ以後てうした比較的高い 温度で，さらに長時間保持してもほとんど 酸化が進行しないてとでうらづけられる。

Fig. 8, 9 それぞれの曲線は, いずれも 酸化反応時間の経過ととあに重量がほぼ比 例的に減少し，乙れらの酸化反応は見かけ 上零次反応であるてとを示す。 


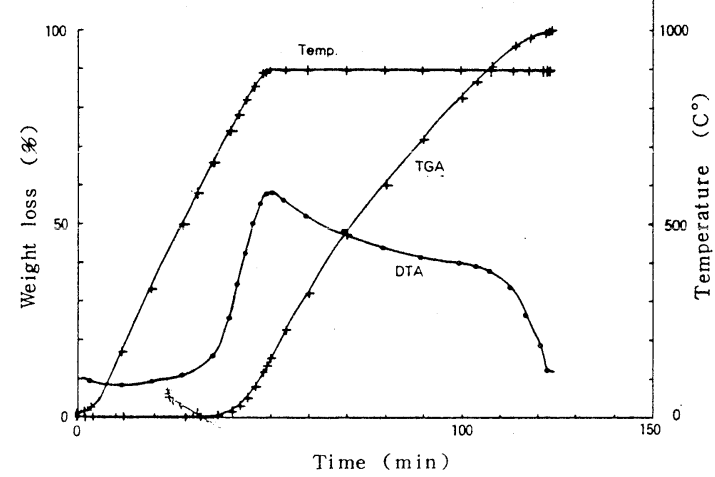

Fig. 5 DTA, TGA and temperature rising curves up to $900^{\circ} \mathrm{C}$ for original carbon in $50 \mathrm{ml} / \mathrm{min}$ of air flow rate

Fig.10は,Fig. 8,9のそれぞれの直線の傾斜から 求めた酸化反応速度定数 $\mathrm{K}$ と 1 / $\mathrm{T}$ との関係を示した Arrhenius 式よりのプロットである。

含浸処理前の黒鉛材料では, $800^{\circ} \mathrm{C}$ 付近に屈曲点が存 在することが明らかとなった。乙れらの結果から計算し た活性化エネルギーは, 高温側で約 $4 \mathrm{Kcal} / \mathrm{mol}$, 低温 側で約 $20 \mathrm{Kcal} / \mathrm{mol}$ であった。乙れに対して含浸処理 後の黒鉛材料は, すべての温度領域にわたってKが小さ く, $750^{\circ} \mathrm{C} \sim 900^{\circ} \mathrm{C}$ の間ではての傾向が特に顕著で, $800^{\circ} \mathrm{C}$ で比較すると含浸処理後のKは処理前の $1 / 50$ 程 度でしかなく，ガラスの含浸処理による耐酸化性の効果 の大きいてとを示している。乙れは，含浸処理するガラ スの溶融温度付近の温度で細孔内のガラスが浸み出して 試料の表面上に酸素を拡散し難いガラスの薄い層を形成 するととによるものと考えられる。

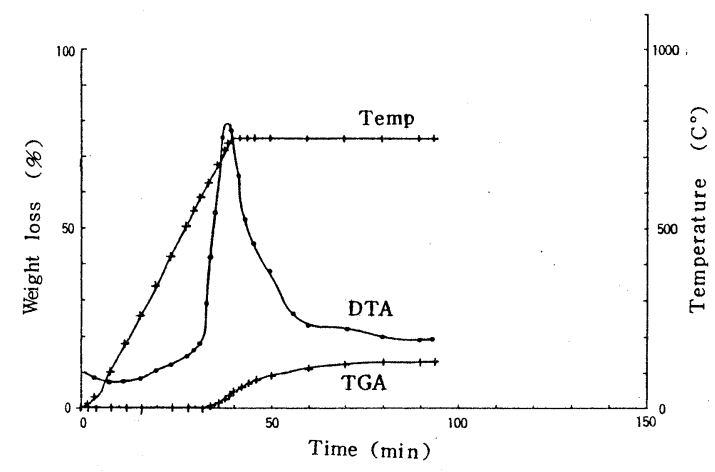

Fig. 6 DTA, TGA and temperature rising cruves up to $750^{\circ} \mathrm{C}$ for No. 2 glass impregnated carbon in $50 \mathrm{ml} / \mathrm{min}$ air flow rate

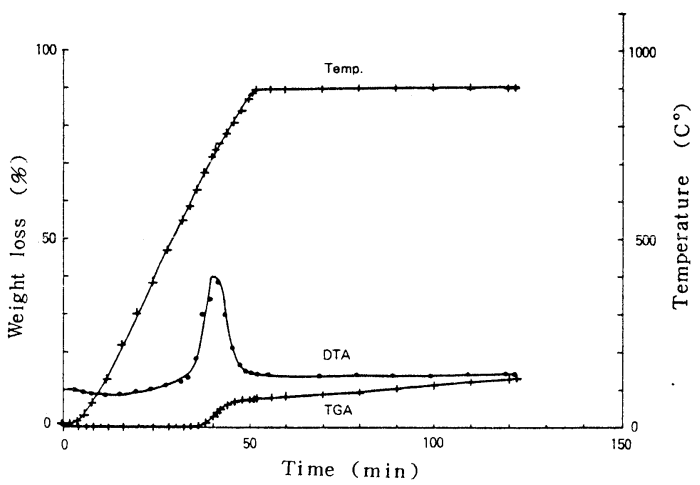

Fig. 7 DTA, TGA and temperature curves up to $900^{\circ} \mathrm{C}$ for No. 2 glass impregnated carbon in $50 \mathrm{ml} / \mathrm{min}$ air flow rate

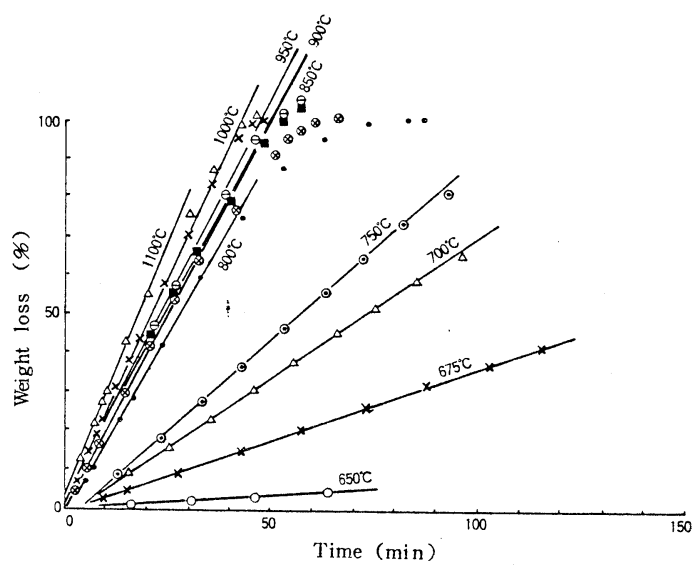

Fig. 8 Oxidation rate curves for original carbon in $50 \mathrm{ml} / \mathrm{min}$ air flow rate at various temperatures

Table 4 は, ガラスの含浸処理前の黒鉛材料之 No. 1, 2, 3 の 3 種類のガラスをそれぞれ黒鉛材料 に含浸した試料について, $800^{\circ} \mathrm{C}, 850^{\circ} \mathrm{C}, 900^{\circ} \mathrm{C}$ の 各温度とその温度で 120 分間保持した時の酸化消耗 率を比較したあのである。No.1のガラスを黒鉛材 料に含浸処理した試料は，酸化消耗率が最も小さく， 次いでNo. 3, No. 2 の順に耐酸化性に対する含浸 効果が大きかった。

てれは, No.1のガラスでは溶融状態での粘度が 他よりも低く，黒鉛材料の表面がほぼ完全にガラス の膜で被覆されたためと説明できるが，No. 2 より も粘度の高いNo. 3 のガラスの方がより大きい耐酸 化性を示したてとについては，乙の実験から明らか にするてとができなかった。 


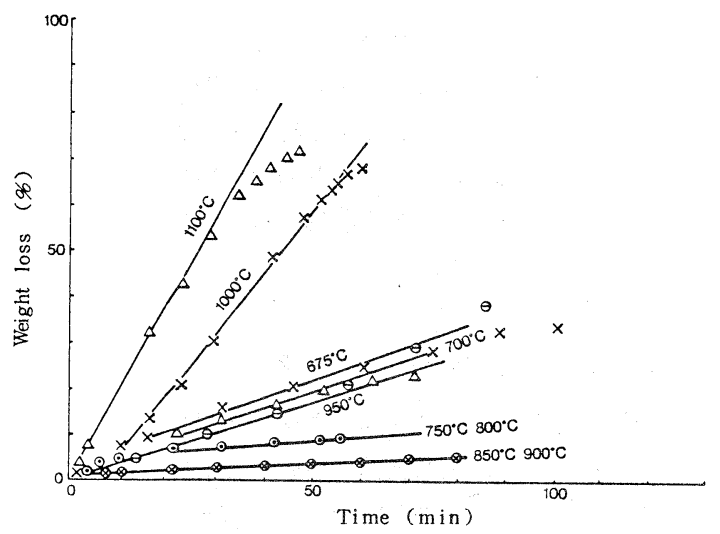

Fig. 9 Oxidation rate curves for No. 2 glass impregnated carbon in $50 \mathrm{ml} / \mathrm{min}$ air flow rate at various temperatures

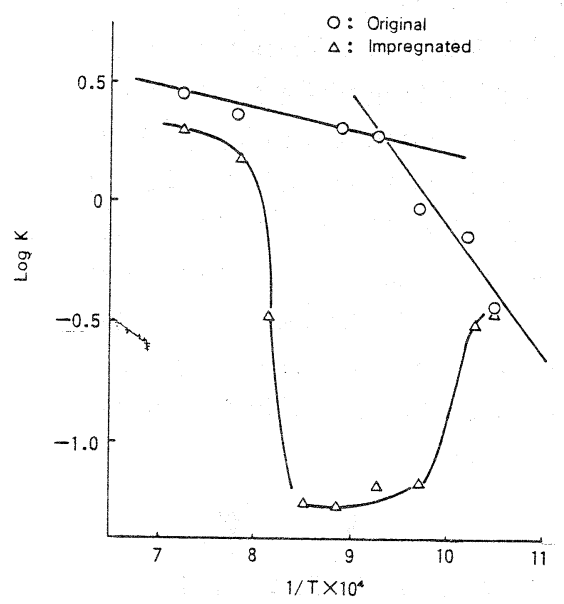

Fig. 10 Arrhenius plots for oxidation reaction of original and glass impregnated carbon

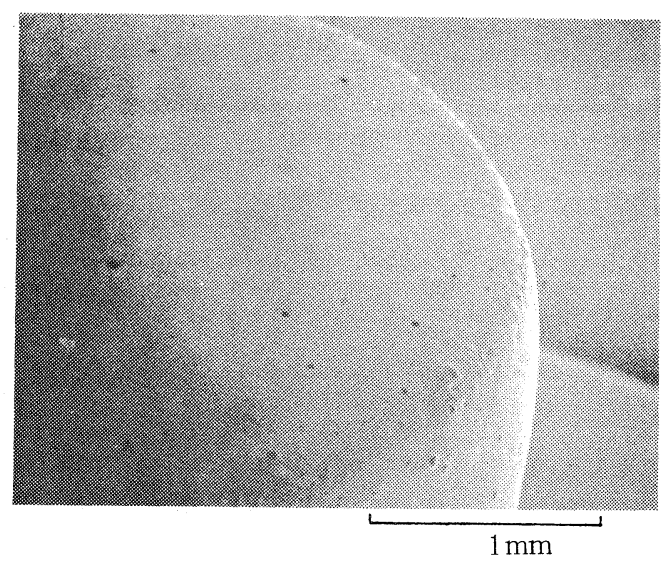

Photo 1a SEM observation of carbon block impregnated with No. 2 glass, after oxidation measurement at $850^{\circ} \mathrm{C}$ for 60 minutes

Photo 1a は, No. 2 のガラスを黒鉛材料に含浸処理 した後, $850^{\circ} \mathrm{C}$ で60分間保持し, 酸化消耗率の測定を行 った試料を走査型電子顕微鏡で観察したものである。 Photo 1b は, 同試料の破断面を示したもので, 数10 $\mu \mathrm{m}$ 程度のガラスによる被膜が炭素表面に形成されてい ることがわかる。

Photo 2 は, 同じくNo. 2 のガラスを含浸処理し, $950^{\circ} \mathrm{C}$ で60分間保持して酸化消耗率を測定した後の試料 の表面を観察したものである。950 $\mathrm{C}$ では，炭素表面に 被覆されているガラスの軟化が進み, ガラスの気泡の部 分より炭素の酸化がはじまる初期的な段階を示している。

これらのことから,ガラス含浸処理した黒鉛材料は, 酸化温度と消耗との間に特異な関係が起る。Fig. 8に見 られるように, 含浸処理前の試料では, 酸化温度の上昇

Table 4 Comparison of weight loss at various temperatures

\begin{tabular}{|c|c|c|c|c|}
\hline & & $\begin{array}{l}\text { heating } \\
\text { temperature }\left({ }^{\circ} \mathrm{C}\right)\end{array}$ & $\begin{array}{l}\text { heating time } \\
(\mathrm{min})\end{array}$ & 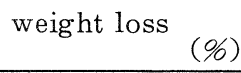 \\
\hline \multirow{3}{*}{$\begin{array}{l}\text { glass } \\
\text { impregnated } \\
\text { carbon }\end{array}$} & No. 1 & $\begin{array}{l}800 \\
850 \\
900 \\
\end{array}$ & $\begin{array}{r}120 \\
120 \\
120 \\
\end{array}$ & $\begin{array}{l}6.1 \\
7.4 \\
9.3 \\
\end{array}$ \\
\hline & No. 2 & $\begin{array}{l}800 \\
850 \\
900 \\
\end{array}$ & $\begin{array}{l}120 \\
120 \\
120 \\
\end{array}$ & $\begin{array}{l}15.0 \\
13.8 \\
11.3 \\
\end{array}$ \\
\hline & No. 3 & $\begin{array}{l}800 \\
850 \\
900 \\
\end{array}$ & $\begin{array}{l}120 \\
120 \\
120 \\
\end{array}$ & $\begin{array}{r}14.4 \\
10.2 \\
9.7\end{array}$ \\
\hline \multicolumn{2}{|c|}{ original carbon } & $\begin{array}{l}800 \\
850 \\
900\end{array}$ & $\begin{array}{r}103 \\
94 \\
87\end{array}$ & $\begin{array}{l}100 \\
100 \\
100\end{array}$ \\
\hline
\end{tabular}




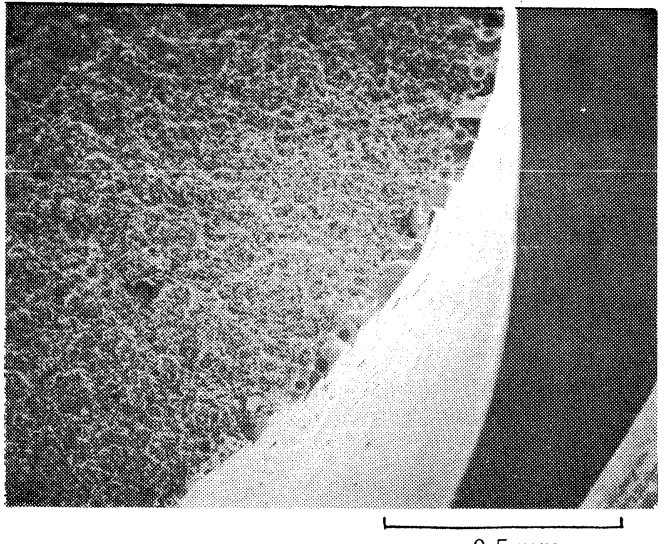

$0.5 \mathrm{~mm}$

Photo 1b SEM observation of broken surface of Photo 1a sample

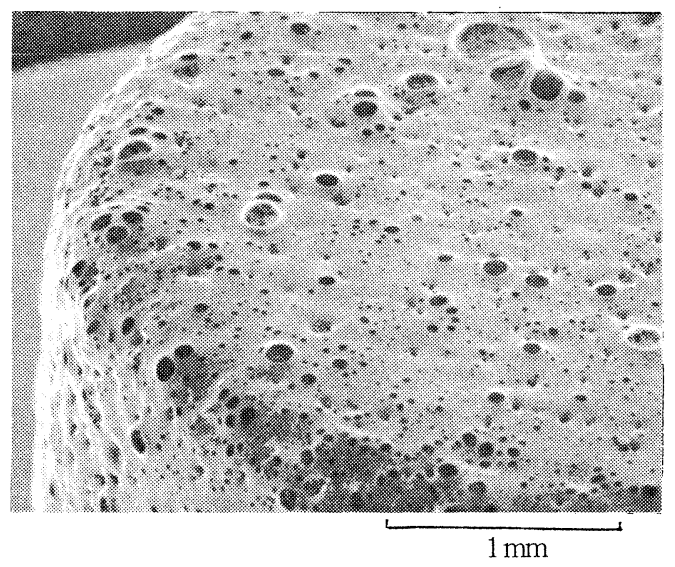

Photo 2 SEM observation of carbon block impregnated with No. 2 glass, after oxidation measurement at $950^{\circ} \mathrm{C}$ for 60 minutes

ととあに酸化消耗による減少速度が大きくなる。含浸処 理した試料では, Fig. 9 亿見られるように, ガラスの軟 化が進まない $675^{\circ} \mathrm{C} \sim 700^{\circ} \mathrm{C}$ では約 $0.46 \% / \mathrm{min}$ 程度の減 少速度であり, $750^{\circ} \mathrm{C} \sim 900^{\circ} \mathrm{C}$ では最む小さく約 $0.1 \% /$ min となる。しかし, $1000^{\circ} \mathrm{C}$ 以上ではガラスの軟化が 進み，その粘度が急激に低下して約 $1.2 \% / \mathrm{min}$ と次第
に酸化による消耗減少速度が大きくなるてとがわかる。

このように黒鉛材料にガラスを含浸処理した試料は, 高温度に打いてガラスによる酸化防止膜が表面に形成さ れる結果。耐酸化性が向上し，普通の黑鉛材料では使用 不可能な温度領域でもあまり消耗することなく，使用を 可能なあのにしている。

\section{4. ま と め}

黑鉛材料の機械的強度を向上させ, 高温での耐酸化性 を付与することが，黒鉛製品についての重要な課題と考 えられる。本研究もその方向の一つの試みとして行った。

黒鉛材料にガラスの含浸処理を行うことによって, 力 サ密度を増加させ気孔率を減少させたてとに伴って不浸 透性を向上させるてとができた。乙の結果として機械的 強度が大きく向上したが, 含浸するガラスの組成を变え 熱膨脹係数を調節して黒鉛母体に近づけることに上って, 含浸一冷却過程での体積収縮率を一致させ, より緊密で より高強度な黑鉛材料を得るととも可能と思わ机る。

ガラス含浸黒鉛材料は, 高温での耐酸化性が向上し, 高温材料としての黑鉛材料の応用をさらに拡大する可能 性を与えるが，含浸するガラスの種類を变えるか，ある いは特殊なガラスを含浸材料として含浸処理後, 熱扔よ

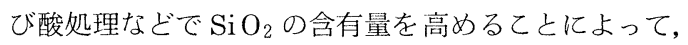
含浸処理温度以上の高温で使用できる黒鉛材料を得るて とも可能になる。

\section{文献}

1) E. R. Booser, D. F. Wilcock, Wear Non-Met. Mater., Proc. Leeds - Lyon Symp Tribology, 3rd, Mech. Eng. Publ. (1978) P.196.

2）鳥羽雄一, 川上紘正, 硫酸と工業 30, 85(1977).

3）池田 茂, 日本特許, 739884 (1974).

4）堀 昭二, 日本特許, 783111 (1975):

5）松尾寛二，日本特許，786529（1975）.

6）池田 茂ほ加, 学振117委員会資料, 163-B2 (1981).

7）池田 茂ほ加, 学振117委員会資料, 165-B 2 (1981).

8) Ikeda, etal., United States Patent, 4461806 (1984). 